\title{
Analisis Implementasi Kebijakan Sistem Pengelolaan Aset Desa (SIPADES) Pemerintah Desa Wukirsari di Kabupaten Sleman
}

\author{
Hanantyo Sri Nugroho a, ${ }^{a, *}$ \\ ${ }^{1}$ Universitas AMIKOM Yogyakarta, Indonesia \\ 1 hanantyosrinugroho@amikom.ac.id \\ *corresponding author
}

\section{ARTICLE INFO}

\section{Article history}

Received 2020-11-15

Revised 2020-12-22

Accepted 2020-12-30

\section{Keywords}

Implementasi Kebijakan, SIPADES

Pemerintah Desa Wukirsari

\begin{abstract}
Penelitian ini mengkaji tentang kebijakan Sistem Pengelolaan Aset Desa (SIPADES). Permasalahan ini menjadi menarik untuk diteliti karena pada saat ini desa memiliki ruang untuk melakukan tata kelola sumber daya (material) setelah adanya kebijakan undang-undang desa. Terdapat perspektif yang digunakan untuk menganalisis permasalahan tersebut yakni perspektif implementasi kebijakan publik. Lebih lanjut, metode penelitian yang digunakan pada penelitian ini adalah metode kualitatif deskriptif. Pada metode kualitatif deskriptif, faktor yang harus diperhatikan adalah validitas data, dimana penelitian ini menggunakan model triangulasi data. Adapun, penelitian ini dilakukan pada Pemerintah Desa Wukirsari di Kabupaten Sleman. Tujuan penelitian ini adalah mengetahui kapasitas pemerintah desa dalam implementasi kebijakan Sistem Pengelolaan Aset Desa (SIPADES). Hasil penelitian adalah terdapat faktor individu, faktor struktur dan faktor budaya yang memiliki hubungan terhadap kapasitas Pemerintah Desa Wukirsari dalam implementasi kebijakan Sistem Pengelolaan Aset Desa (SIPADES).
\end{abstract}

\section{PENDAHULUAN}

Desa saat ini telah memiliki alokasi anggaran yang besar dimana dianggarkan oleh pemerintah pusat. Hal ini menjadi komitmen negara untuk membangun Indonesia yang dimulai dari struktur pemerintahan paling kecil. Setidaknya itu menjadi ruang bagi pemerintah desa setelah lama menjadi inferior pada supra sistem yang ada. Nantinya, alokasi anggaran tersebut diharapkan dapat mempercepat terwujudnya desa yang mandiri, sejahtera, dan demokratis. Dengan demikian, kemampuan pemerintah desa pada pengelolaan aset desa memiliki posisi strategis dalam pelaksanaan kesejahteraan masyarakat.

Pada perkembangannya, pemerintah pusat telah menetapkan kebijakan tata kelola pemerintah desa berbasis elektronik, yakni salah satunya adalah Sistem Pengelolaan Aset Desa (SIPADES). Aplikasi Sistem Pengelolaan Aset Desa (SIPADES) yang diinisiasi oleh Direktorat Jenderal Pemerintah Desa Kementerian Dalam Negeri memiliki tujuan agar memudahkan pengelolaan aset desa yang transparan dan akuntabel, meminimalisir resiko hilangnya aset desa, mempermudah kepala desa dalam menyampaikan laporan kekayaan milik desa, serta sebagai alat bantu pemerintah desa dalam tata kelola aset desa. Adapun, aplikasi sistem Sistem Pengelolaan Aset Desa (SIPADES) ini telah dimulai sejak tahun 2018.

Lebih lanjut, masih terdapat permasalahan dan tantangan pada kapasitas pemerintah desa dalam menjalankan kebijakan tersebut. Munculnya alokasi anggaran yang besar yang dimiliki pemerintah desa tersebut kemudian memunculkan konsekuensi tentang bagaimana kapasitas pemerintah desa untuk melakukan tertib administrasi dalam penggunaan aset desa. Salah satu permasalahan dan tantangan pada kapasitas pemerintah desa adalah keterbatasan kemampuan pemerintah desa dalam melakukan tertib administrasi pada penggunaan aset desa. Permalahan dan tantangan pengelolaan aset desa yakni terkait kodefikasi aset desa, dimana kebijakan aset desa pada Permendagri Nomor 1 Tahun 2016 tidak hanya berbicara aset desa berupa fisik, melainkan juga sumber daya alam, sumber daya manusia, dan aset kelembagaan, serta aset sosial lainnya. Hal tersebut yang kemudian menjadi hambatan dan tantangan bagi pemerintah desa dalam mengimplementasikan kebijakan tersebut. Hal ini dikarenakan banyaknya aset desa yang harus dilaporkan dan lama waktu yang diperlukan dalam proses pelaporan tersebut.

Meskipun demikian, terdapat perbedaan temuan penelitian apabila dibandingkan dengan kondisi 
implementasi kebijakan Sistem Pengelolaan Aset Desa (SIPADES) Pemerintah Desa Wukirsari di Kabupaten Sleman. Pada implementasi Sistem Pengelolaan Aset Desa (SIPADES), terdapat inovasi yang dilakukan oleh Pemerintah Desa Wukirsari berupa dapat melakukan proses input dan mengolah 1500 data dalam kurun waktu 4 jam. Dengan demikian, kapasitas birokrasi pemerintah desa dalam tata kelola sumber daya tersebut memadai sehingga implementasi kebijakan tata kelola sumber daya aset desa. Oleh karena itu, penelitian ini menggunakan konsep bahwa terdapat kondisi ideal dalam pelaksanaan inovasi sehingga mendorong inovasi dari waktu ke waktu (Bennett, 2004). Kondisi ideal tersebut tergambarkan dari beberapa faktor atau kegiatan yang saling terkait. Faktor yang dimaksud adalah faktor individu, faktor struktur.

\section{TINJAUAN PUSTAKA}

\section{Implementasi Kebijakan Publik}

Analisis implementasi kebijakan adalah proses mempelajari faktor keberhasilan atau kegagalan suatu kebijakan publik. Artinya, proses tersebut terkait dengan faktor-faktor yang mempengaruhi implementasi kebijakan. Faktor-faktor ini seperti kepemimpinan, interaksi politik antara pelaksana kebijakan. Namun, analisis implementasi kebijakan tidak hanya bersifat administratif, tetapi juga melihat kondisi sosial-politik yang terjadi ketika menerapkan kebijakan tersebut. Dengan demikian, studi implementasi kebijakan mencoba menjawab terkait mengapa itu bisa terjadi, yang tidak berhenti pada apa yang terjadi. Sementara itu, kegagalan implementasi kebijakan dapat dibagi menjadi dua kategori (Wahab, 1990), yaitu tidak menerapkan kebijakan dimana tindakan ini menyiratkan bahwa suatu kebijakan tidak dilaksanakan sesuai dengan rencana, serta kegagalan kebijakan, dimana ini terjadi ketika kebijakan tertentu telah diterapkan, tetapi kondisi eksternal kebijakan tersebut tidak mendukung sehingga kebijakan tersebut tidak menghasilkan dampak yang diinginkan atau hasil akhir. Selain itu, ada beberapa faktor yang mempengaruhi keberhasilan implementasi (Agustino 2006), yakni:

a. Ukuran dan Tujuan Kebijakan. Kinerja implementasi kebijakan dapat diukur dalam hal keberhasilan jika dan hanya ukuran dan tujuan kebijakan yang realistis dengan kondisi sosialbudaya di tingkat implementasi kebijakan.

b. Sumberdaya. Tahap-tahap tertentu dari keseluruhan proses implementasi membutuhkan sumber daya manusia yang berkualitas sesuai dengan pekerjaan yang dibutuhkan oleh kebijakan yang ditentukan secara politis. Selain itu, ada sumber daya keuangan dan sumber daya waktu yang sering menjadi masalah publik untuk mewujudkan tujuan kebijakan yang dimaksudkan.

e. Sikap Badan Pelaksana. Kebijakan yang akan diterapkan oleh pelaksana adalah kebijakan topdown di mana sangat mungkin bahwa pengambil keputusan tidak tahu atau tidak mampu menyentuh kebutuhan, keinginan, atau masalah yang diinginkan oleh warga.

f. Komunikasi antara Organisasi dan Kegiatan Pelaksana. Koordinasi adalah mekanisme yang kuat dalam implementasi kebijakan publik. Komunikasi yang sering akan mengurangi kesalahan.

g. Lingkungan Ekonomi, Sosial dan Politik. Lingkungan eksternal membantu mendorong keberhasilan kebijakan publik yang telah diterapkan. Lingkungan yang tidak kondusif dapat menjadi penyebab kegagalan kinerja implementasi kebijakan.

\section{Inovasi Kebijakan Publik}

Penelitian ini bahwa ada kondisi ideal dalam menerapkan inovasi sehingga dapat mendorong inovasi dari waktu ke waktu (Bennett, 2004). Faktor-faktor yang mempengaruhi kondisi ideal tersebut adalah faktor inidividu, struktural, dan budaya. Pada faktor individu terdapat unsur motivasi, norma, dan harmoni. Selanjutnya, pada faktor struktural terdapat unsur aturan dan komunikasi, insentif, keterbukaan, serta keseimbangan. Lebih lanjut, pada faktor budaya terdapat unsur guncangan (katalitik), pengelompokan, dan pengakuan. Dengan demikian, ketika faktor individu, faktor struktural, dan faktor budaya memunculkan konsekuensi peningkatan inovasi dalam implementasi kebijakan.

Pada faktor individu meliputi motivasi, norma, dan harmoni. Motivasi adalah bagaimana faktor stimulus pada seseorang untuk melakukan perubahan dengan melakukan berbagai pertimbangan yang didasarkan pada pilihan rasional. Pada unsur norma, individu yang mngejar perubahan cenderung mengalami ketidakharmonisan dengan kolega lain. Pada unsur harmoni, keselarasan memunculkan konsekuensi antara nilai individu dengan nilai kelembagaan. Apabila nilai individu tidak selaras dengan nilai kelembagaan, maka individu sulit untuk terlibat dalam usaha inovasi. Pada faktor struktural, 
struktur mencakup aturan dan komunikasi, insentif, dan keterbukaan. Aturan dan komunikasi adalah bagaimana inovasi berkelanjutan harus memberikan dukungan administratif yang jelas. Hal tersebut memberikan peluang untuk mengimplementasikan inovasi. Insentif harus mengakomodir dari pilihan untuk rugi individu yang berpartisipasi dalam melakukan inovasi, dimana pemberian insentif yang sesuai. Lebih lanjut, keterbukaan memberikan konsekuensi terhadap keterbukaan struktur yang ada terhadap perubahan. Pada faktor budaya, terdapat unsur guncangan, pengelompokkan, dan pengakuan. Guncangan mengacu kepada momentum pada peristiwa yang melatarbelakangi sebuah inovasi. Pengelompokkan digunakan untuk mendorong kelompok yang dirugikan untuk melakukan upaya memberikan artikulasi maupun agregasi kepentingan agar terus tercipta solusi alternatif. Pada unsur pengakuan, usaha inovasi akan memberikan manfaat kepada semua unsur kepentingan yang ada agar melakukan suatu usaha inovasi, terutama yang sesuai dengan persepsi masyaakat. Dengan demikian, ketika faktor individu, faktor struktural, dan faktor budaya selaras dan berkelanjutan, kemungkinan peningkatan inovasi dapat diimplementasikan. Ketika faktor-faktor tidak selaras dan/atau tidak didukung pada satu atau lebih tingkat hierarki, kemungkinan berinovasi berkurang.

\section{METODE PENELITIAN}

Penelitian ini adalah implementasi kebijakan Sistem Pengelolaan Aset Desa (SIPADES) Pemerintah Desa Wukirsari di Kabupaten Sleman. Oleh karena itu, penelitian ini dilakukan di Pemerintah Desa Wukirsari. Selanjutnya, pendekatan yang digunakan dalam penelitian ini adalah studi kasus. Studi kasus adalah metode penelitian yang melakukan penelitian pada beberapa atau semua aspek potensial dari suatu unit atau serangkaian kasus tertentu. Sementara itu, metode penelitian yang akan digunakan oleh peneliti adalah metode penelitian deskriptif kualitatif. Metode kualitatif deskriptif, sebagai prosedur penelitian yang menghasilkan data deskriptif dalam bentuk kata-kata tertulis atau lisan dari orang-orang dan perilaku yang dapat diamati (Moleong, 2002). Sementara itu, metode penelitian kualitatif fokus pada tindakan manusia, proses pembentukan tindakan, dan interaksi sosial (Muhadjir, 2000).

Tahap awal penelitian dilakukan dengan memetakan masalah, teori, dan peraturan yang berkaitan dengan tata kelola sumber daya (material) desa. Karena itu, pada tahap ini termasuk diskusi internal dengan Pemerintah Desa. Ini bertujuan untuk menemukan peraturan, dokumen kerja sama, dan referensi terkait lainnya. Dengan demikian, tahap awal penelitian ini dapat berkontribusi pada tahap berikutnya dalam bentuk studi mendalam tentang fokus dan perumusan masalah dalam penelitian ini. Selanjutnya, metode analisis data yang digunakan adalah analisis data interaktif yaitu analisis yang dilakukan dalam bentuk interaktif pada 3 (tiga) komponen utama yang saling terkait satu sama lain (Milles, 1994):

a. Reduksi data yang diartikan sebagai proses pemilihan pemusatan perhatian pada penyerderhanaan, pengabstrakan, dan transformasi data "kasar" yang muncul dari catatan-catatan tertulis di lapangan.

b. Sajian data. Sub proses ini merupakan suatu bentuk "penyajian" yang diartikan sebagai sekumpulan informasi tersusun yang memberi kemungkinan adanya penarikan kesimpulan dan pengambilan tindakan.

c. Penarikan kesimpulan atau diversifikasi. Dalam sub proses ini, peneliti mulaimelakukan tindakan interpretasi yaitu memberikan makna pada data atau informasi yang telah disaji.

Proses analisis ini berlanjut seperti siklus. Para peneliti bergerak di antara ketiganya. Ini dimaksudkan untuk memahami dan mendapatkan pemahaman yang mendalam, komprehensif, dan terperinci sehingga menghasilkan kesimpulan sebagai hasil dari pemahaman peneliti.

Dalam penelitian kualitatif faktor penting yang harus diperhatikan adalah validitas data, untuk mengetahui validitas data, penelitian ini menggunakan model triangulasi data. Triangulasi adalah teknik pengecekan validitas data yang memanfaatkan sesuatu selain data untuk keperluan pengecekan atau perbandingan (Moleong, 2002). Selain itu, ada juga yang membedakan 4 jenis triangulasi sebagai teknik pemeriksaan yang memanfaatkan penggunaan sumber, metode, peneliti dan teori (Moleong, 2002). Triangulasi data dalam penelitian ini akan dicapai dengan cara peneliti akan mengecek ulang informasi yang diberikan. Selain itu, informasi yang diperoleh akan diuji keakuratannya dengan data pengamatan serta data dari pengamatan terkait dengan topik penelitian ini. Proses analisis data tersebut dapat disimplifikasikan pada gambar 1. 


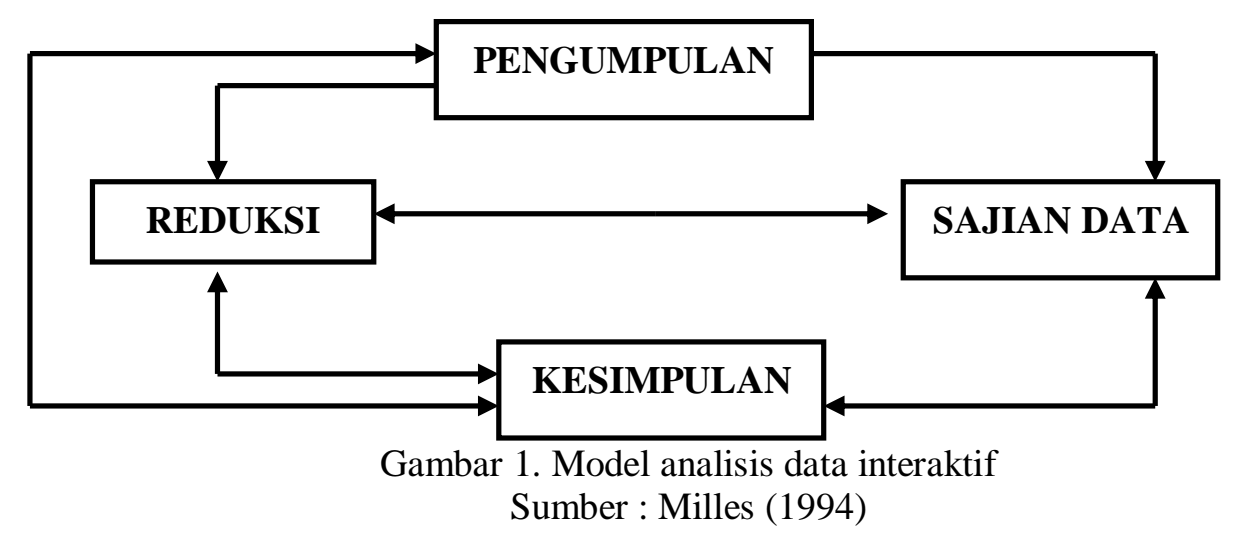

\section{HASIL DAN PEMBAHASAN}

Implementasi kebijakan pengelolaan aset desa di Pemerintah Desa Wukirsari masih mengalami hambatan berupa proses penginputan aset yang memerlukan waktu yang lama dan juga banyaknya aset yang harus diinputkan pada aplikasi Sistem Pengelolaan Aset Desa (SIPADES). Meskipun demikian, Pemerintah Desa Wukirsari sudah dapat melakukan proses penginputan dan pengolahan data untuk 1500 aset dalam waktu 4 jam. Artinya, hal ini dapat menunjukkan kemampuan Pemerintah Desa Wukirsari dalam melakukan proses penginputan, dimana proses penginputan 1 identitas aset desa dapat membutuhkan waktu berkisar pada 7-10 menit. Dengan demikian, kapasitas birokrasi Pemerintah Desa Wukirsari memadai dalam tata kelola pengelolaan aset desa sehingga implementasi kebijakan pengelolaan aset desa dapat berjalan dengan baik dan juga memberikan manfaat bagi pemerintah desa.

Pada aspek ukuran dan tujuan kebijakan, kebijakan pengelolaan aset desa merupakan implikasi dari Peraturan Menteri Dalam Negeri Nomor 1 Tahun 2016 tentang Pengelolaan Aset Desa. Berdasarkan pada Peraturan Menteri Dalam Negeri Nomor 1 Tahun 2016, kebijakan pengelolaan aset desa memiki tujuan agar penatausahaan aset desa yang meliputi pembukuan, inventarisasi dan pelaporan kekayaan milik desa dapat terwujud dengan tertib, efektif, dan optimal sesuai prinsip-prinsip pengelolaan aset pada umumnya. Kebijakan pengelolaan aset desa melalui sistem elektronik membawa konsekuensi terhadap kodefikasi aset desa. Hal ini bertujuan agar terciptanya kesamaan persepsi di lingkungan pemerintah desa, serta penggolongan dan kodefikasi aset desa yang baku dan seragam secara nasional. Adapun, sasaran dari kebijakan pengelolaan aset desa yakni (Dirjen Bina Pemerintahan Desa, 2017):

a. Kekayaan asli desa

b. Kekayaan milik desa yang dibeli atau diperoleh atas beban APBDesa

c. Kekayaan desa yang diperoleh dari hibah dan sumbangan atau yang sejenisnya

d. Kekayaan desa yang diperoleh sebagai pelaksanaan dari perjanjian/kontrak dan/atau diperoleh berdasarkan ketentuan peraturan undang-undang

e. Hasil kerjasama desa

f. Kekayaan desa yang berasal dari perolehan lain yang sah

Artinya, tujuan kebijakan pengelolaan aset desa memiliki tujuan untuk mewujudkan tertib administrasi. Meskipun demikian, masih terdapat kendala pada proses penginputan aset desa. Kendala proses penginputan berupa lamanya proses penginputan aset desa tersebut. Oleh karena proses penginputannya membutuhkan waktu yang lama pada saat penambahan aset desa pada tiap tahunnya. Proses penginputan 1 identitas aset desa membutuhkan waktu berkisar pada 7-10 menit. Adapun, jumlah aset desa di Desa Wukirsari adalah sekitar 1800 aset. Selain itu, aplikasi kebijakan pengelolaan aset desa dirasakan tidak komplit untuk tata kelola aset desa. Dengan demikian, tujuan kebijakan sebenarnya sudah benar yakni mendukung tertib administrasi dalam pengelolaan desa, meskipun aplikasi dari kebijakan ini kurang aplikatif sehingga kurang berhasil dalam mengimplementasikan kebijakan tersebut.

Pada aspek sumberdaya, Pemerintah Desa Wukirsari telah memiliki struktur organisasi dengan pembagian kerja yang jelas. Adapun, struktur organisasi Pemerintah Desa Wukirsari terdiri dari: 


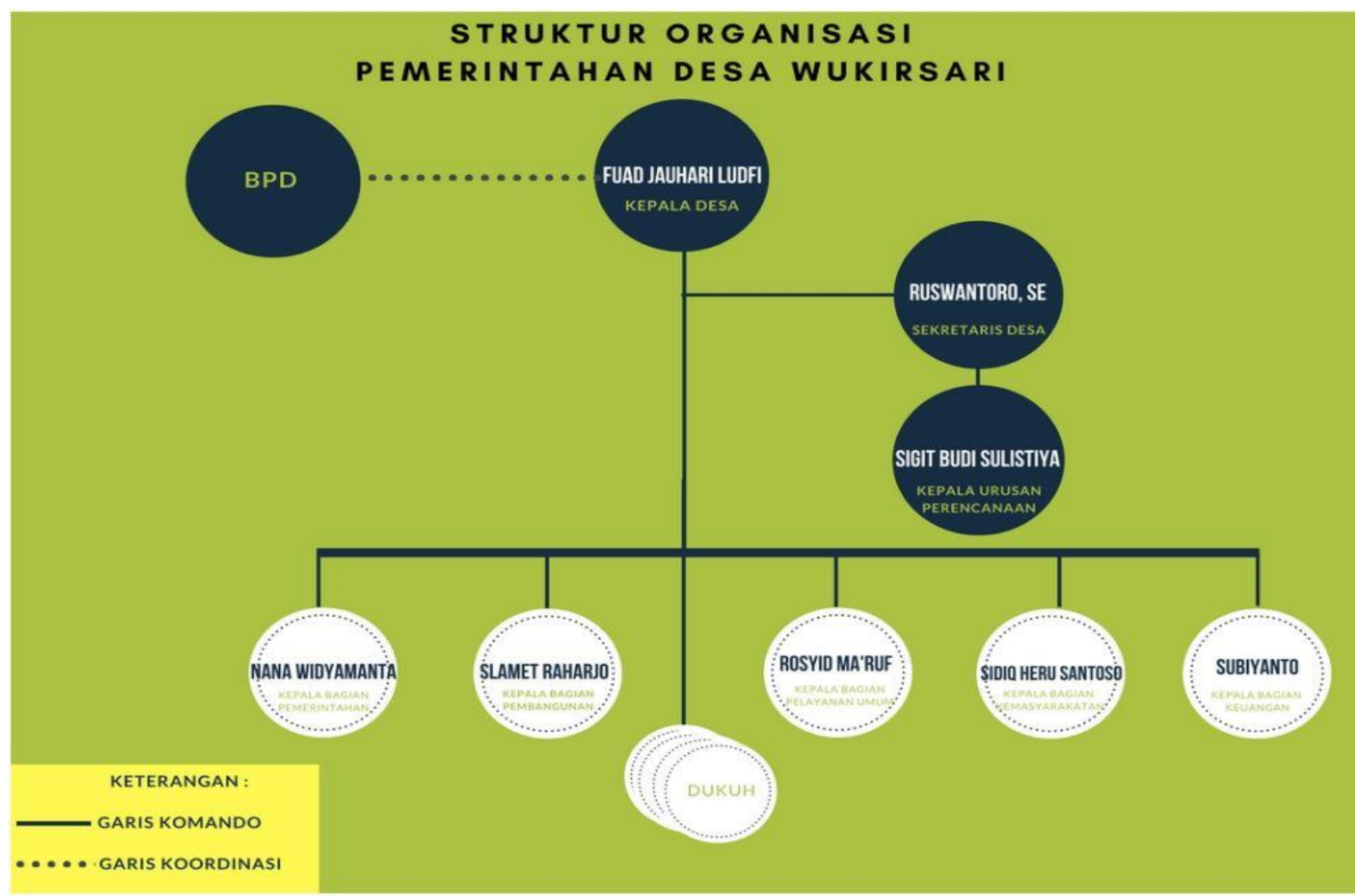

Gambar 2. Struktur Organisasi Pemerintah Desa Wukirsari

Pada pengelolaan aset desa, Pemerintah Desa Wukirsari sudah dapat melakukan proses penginputan dan pengolahan data untuk 1500 aset dalam waktu 4 jam. Hal ini juga merupakan penyesuaian dari Permendagri No.1 Tahun 2016. Artinya, Pemerintah Desa Wukirsari telah memiliki sumberdaya manusia yang mampu melakukan proses penginputan dan pengolahan data lebih cepat.

Pada aspek sikap badan pelaksana, kebijakan pengelolaan aset desa bersifat top-down dimana kebijakan tersebut menggunakan Aplikasi Sistem Pengelolaan Aset Desa (SIPADES). Hal ini kemudian memunculkan konsekuensi terhadap tantangan pada implementasi kebijakan tersebut, dimana kurang aplikatif dan komplit dalam penatausahaan aset desa. Adapun, sikap Pemerintah Desa Wukirsari adalah tetap melaksanakan proses penatausahaan aset desa dengan menggunakan Aplikasi Sistem Pengelolaan Aset Desa (SIPADES) yang sudah menjadi suatu kebijakan sebagai bentuk tertib administrasi. Dengan demikian, masih terdapat kendala pada implementasi kebijakan pengelolaan aset desa melalui Aplikasi Sistem Pengelolaan Aset Desa (SIPADES).

Pada aspek komunikasi antara organisasi dan kegiatan pelaksana, Pemerintah Desa Wukirsari tetap melakukan koordinasi dengan Pemerintah Kecamatan Cangkringan dan juga Pemerintah Kabupaten Sleman dalam pelaksanaan implementasi kebijakan pengelolaan aset desa. Komunikasi tersebut terkait sosialisasi dan implementasi dari adanya perubahan aplikasi yang digunakan sebagai bagian dari kebijakan pengelolaan aset desa di Kabupaten Sleman. Pada awal pelaksanaan kebijakan pengelolaan aset desa, aplikasi sistem pengelolaan aset desa di Kabupaten Sleman menggunakan program Sistem Keuangan Desa (Sikudes). Akan tetapi, program Sikudes kemudian berganti menjadi Sistem Informasai Debet Kredit untuk Desa (Sidek Desa). Artinya, komunikasi Pemerintah Kabupaten Sleman dengan Pemerintah Desa Wukirsari berjalan dengan baik. Selain itu, Pemerintah Desa Wukirsari melakukan koordinasi dengan Pemerintah Kecamatan Cangkringan terkait dengan pelaksanaan implementasi kebijakan pengelolaan aset desa.

Pada aspek lingkungan sosial ekonomi dan politik, aspek tersebut tidak berhubungan terhadap pelaksanaan implementasi kebijakan pengelolaan aset desa di Pemerintahan Desa Wukirsari. Oleh karena, aspek sumberdaya maupun aspek komunikasi yang lebih memberikan kontribusi bagi implementasi kebijakan pengelolaan aset desa tersebut. Hal tersebut dapat terlihat pada proses penginputan aset desa yang dilakukan oleh Pemerintah Desa Wukirsari. Dengan demikian, implementasi kebijakan pengelolaan aset desa tersebut lebih dipengaruhi oleh aspek lingkungan internal Pemerintah Desa Wukirsari. 


\section{KESIMPULAN}

Implementasi kebijakan pengelolaan aset desa di Pemerintah Desa Wukirsari masih mengalami hambatan berupa proses penginputan aset yang memerlukan waktu yang lama dan juga banyaknya aset yang harus diinputkan pada aplikasi Sistem Pengelolaan Aset Desa (SIPADES). Meskipun demikian, Pemerintah Desa Wukirsari sudah dapat melakukan proses penginputan dan pengolahan data untuk 1500 aset dalam waktu 4 jam. Artinya, hal ini dapat menunjukkan kemampuan Pemerintah Desa Wukirsari dalam melakukan proses penginputan, dimana proses penginputan 1 identitas aset desa dapat membutuhkan waktu berkisar pada 7-10 menit. Dengan demikian, kapasitas birokrasi Pemerintah Desa Wukirsari memadai dalam tata kelola pengelolaan aset desa sehingga implementasi kebijakan pengelolaan aset desa dapat berjalan dengan baik dan juga memberikan manfaat bagi pemerintah desa. Pada aspek ukuran dan tujuan kebijakan, kebijakan pengelolaan aset desa merupakan implikasi dari Peraturan Menteri Dalam Negeri Nomor 1 Tahun 2016 tentang pengelolaan aset desa. Kebijakan pengelolaan aset desa memiki tujuan agar penatausahaan aset desa yang meliputi pembukuan, inventarisasi dan pelaporan kekayaan milik desa dapat terwujud dengan tertib, efektif, dan optimal sesuai prinsip-prinsip pengelolaan aset pada umumnya. Artinya, tujuan kebijakan pengelolaan aset desa memiliki tujuan untuk mewujudkan tertib administrasi. Pada aspek sikap badan pelaksana, kebijakan pengelolaan aset desa bersifat top-down dimana kebijakan tersebut menggunakan Aplikasi Sistem Pengelolaan Aset Desa (SIPADES). Hal ini kemudian memunculkan konsekuensi terhadap tantangan pada implementasi kebijakan tersebut, dimana kurang aplikatif dan komplit dalam penatausahaan aset desa. Pada aspek komunikasi antara organisasi dan kegiatan pelaksana, Pemerintah Desa Wukirsari tetap melakukan koordinasi dengan Pemerintah Kecamatan Cangkringan dan juga Pemerintah Kabupaten Sleman dalam pelaksanaan implementasi kebijakan pengelolaan aset desa. Pada awal pelaksanaan kebijakan pengelolaan aset desa, aplikasi sistem pengelolaan aset desa di Kabupaten Sleman menggunakan program Sistem Keuangan Desa (Sikudes). Akan tetapi, program Sikudes kemudian berganti menjadi Sistem Informasai Debet Kredit untuk Desa (Sidek Desa). Artinya, komunikasi dan koordinasi yang dilakukan terkait dengan sosialisasi maupun implementasi dari adanya perubahan aplikasi yang digunakan tersebut. Pada aspek lingkungan sosial ekonomi dan politik, implementasi kebijakan pengelolaan aset desa di Desa Wukirsari lebih dipengaruhi oleh aspek lingkungan internal Pemerintah Desa Wukirsari.

\section{DAFTAR PUSTAKA}

Agustino, Leo. 2006. Dasar-Dasar Kebijakan Publik. Bandung: CV Alfabeta.

Bennett, R. J. 2004. Implementing innovation. In ASEE Annual Conference Proceedings. https://doi.org/10.1177/107554708300500204

Direktorat Jenderal Bina Pemerintahan Desa. 2017. Pedoman Umum Kodefikasi Aset Desa. Jakarta: Kementerian Dalam Negeri Republik Indonesia

Peraturan Menteri Dalam Negeri Nomor 1 Tahun 2016 tentang Pengelolaan Aset Desa.

Moleong, Lexy J. 2002. Metodologi Penelitian Kualitatif. Bandung: PT. Remaja Rosdakarya.

Muhadjir, Noeng. 2000. Metodologi Penelitian Kualitatif. Yogyakarta: Rake Sarasin.

Milles, Mattew B. and A. Michael Huberman. 1994. Qualitative Data Analysis: An Expanded Sourcebook. New Delhi: SAGE Publications.

Wahab, Solichin Abdul. 2005. Analisis Kebijaksanaan dari Formulasi ke Implementasi Kebijaksanaan Negara. Jakarta: PT Bumi Aksara. 